\title{
UM DISCURSO QUE DERRUBA MURALHAS: REFLEXÕES SOBRE A RIQUEZA E FORÇA DA VOZ DE/EM BARACK OBAMA
}

\author{
Tiago Costa Pereira ${ }^{1}$ (UFSC)
}

Resumo: Este trabalho pretende apresentar reflexões acerca da noção de performance principalmente a partir do que propõe o medievalista Paul Zumthor - e da voz pensada antes de qualquer sistema de significação. Estas problematizações partem, também e majoritariamente, da performance vocal do discurso "The great need of the hour", de Barack Obama.

Palavras-chave: performance; esquizofonia; materialidade.

- Isso é incrível! - disse Nasbitt, entusiasmado.

- Você parece um astro de rock!

- Obama voltou-se para o amigo e respondeu:

- Se você está achando isso demais, espere até amanhã.

- Como assim? - perguntou Nasbitt, com uma expressão intrigada no rosto.

- Meu discurso é muito bom - explicou Obama. ${ }^{2}$

Este diálogo foi extraído de um dos, aproximadamente, cento e cinquenta e oito mil livros relacionados a Barack Obama e enumerados pela ferramenta de busca do Google. Na introdução de O Deus de Barack Obama, o escritor e historiador estadunidense Stephen Mansfield relata a conversa do então sequer senador Barack Hussein Obama e seu amigo Martin Nasbitt. Segundo Mansfield (2008, p. 14), Nasbitt estava fascinado com a "ávida multidão" que "se amontoava e se espremia para chegar mais perto do magro e negro" Obama às vésperas de seu discurso na Convenção Nacional do Partido Democrata, em julho de 2004. O discurso de dezessete minutos foi assim percebido e descrito por Mansfield (2008, p. 14):

[...] Havia uma sinalização a respeito das limitações do governo para resolver os problemas, um convite ao fim da disputa política que partia a alma da nação. As Escrituras e a poesia da experiência americana elegantemente trazidas à tona, tudo incensado pela própria história de Obama e pela promessa 'de que um garoto magricela de nome engraçado que acreditava que os Estados Unidos tinham um lugar guardado pra ele', poderia significar alguma coisa para as outras pessoas.

Foi uma performance de mestre. [grifos nossos]

\footnotetext{
${ }^{1}$ Mestrando do Programa de Pós Graduação em Literatura da Universidade Federal de Santa Catarina. E-mail: tiago_hst@hotmail.com

2 MANSFIELD, Stephen. O Deus de Barack Obama: porque não existe liderança sem fé. Tradução de Nathalia Molina. Rio de Janeiro : Thomas Nelson Brasil, 2008, p. 13.
} 
A intenção deste trabalho não é verificar se Mansfield tem ou não razão ao classificar o discurso como uma "performance de mestre", ou atribuir ao desempenho nos palanques o fato de Obama ter se tornado o primeiro negro a ser eleito presidente dos Estados Unidos da América. Mas, um presidente que mais se parece com um astro de rock, que tem a desenvoltura de trazer poesia e Escrituras ao discurso político parece ser um bom ponto de partida para algumas reflexões acerca das noções de performance, da oralidade, da materialidade e corporeidade presentes na voz. Talvez, pensar estas questões a partir de alguns discursos de Obama, ou apenas constituir o espaço deste trabalho como reflexão sobre a importância da voz, da vocalidade e contribuir para resgatar a riqueza da oralidade, do movimento da palavra viva que foi, aos poucos, perdendo espaço para a fixidez do texto, segundo Zumthor (1993).

Abordar a noção de performance e, principalmente, a de performance vocal sem recorrer às obras do medievalista Paul Zumthor seria, no mínimo, um equívoco. Em Performance, recepção, leitura, Zumthor (2007) dedica quase a totalidade de sua obra a este conceito. Ainda no prefácio da referida obra, o historiador reivindica uma ampliação para a noção de performance e que esta deveria ser estendida ao conjunto de fatos do que, hoje, se costuma atribuir à percepção.

Um exemplo trazido por Zumthor (2007, p. 28), embora extenso e de uma realidade extremamente distante, parece interessante para uma reflexão acerca da "performance de mestre" de Obama.

[...] Entro nessa matéria pela evocação de uma lembrança que não apenas me é cara mas que está profundamente inscrita $\mathrm{em} \mathrm{mim,} \mathrm{permaneceu} \mathrm{subjacente} \mathrm{a}$ tudo o que eu ensinei nos últimos quinze anos. Isto tem a ver com a minha infância parisiense, as idas e vindas entre o subúrbio onde habitavam meus pais e o colégio do nono distrito no qual, no começo dos anos 1930, eu fazia meus estudos secundários. Nessa época, as ruas de Paris eram animadas por numerosos cantores de rua. Eu adorava ouvi-los: tinha meus cantos preferidos, como a rua do Faubourg, Montmatre, a rua Saint Denis, meu bairro de estudante pobre. Ora, o que percebíamos dessas canções? Éramos quinze ou vinte troca-pernas em trupe ao redor de um cantor. Ouvia-se uma ária, melodia muito simples, para que na última copla pudéssemos retomá-la em coro. Havia um texto, em geral muito fácil, que se podia comprar por alguns trocados, impresso grosseiramente em folhas volantes. Além disso, havia o jogo. O que nos havia prendido era o espetáculo. Um espetáculo que me prendia, apesar da hora de meu trem que avançava e me fazia correr em seguida até a Estação do Norte.

Havia o homem, o camelô, sua parlapatice, porque ele vendia as canções, apregoava e passava o chapéu; as folhas-volantes em bagunça num guarda-chuva emborcado na beira da calçada. Havia o grupo, o riso das meninas, sobretudo no fim da tarde, na hora em que as vendedoras saíam de suas lojas, a rua em volta, os barulhos do mundo e, por cima, o céu de Paris que, no começo do inverno, sob as nuvens de neve, se tornava violeta. Mais ou menos tudo isto 
fazia parte da canção. Era a canção. Ocorreu-me comprar o texto. Lê-lo não ressuscitava nada. Aconteceu-me cantar de memória a melodia. A ilusão era um pouco mais forte mas não bastava, verdadeiramente.

Um pouco mais adiante, Zumthor (2007, p. 29) conclui:

[...] Passados sessenta anos, pude compreender que, desde então, inconscientemente, não cessei de buscar o que ficou, em minha vida, daquele prazer que então senti: o que me restou no consumo (em certos momentos bulímicos) que fiz, ao longo dos anos, daquilo que chamamos "literatura". A forma da canção de meu camelô de outrora pode se decompor, analisar, segundo as frases ou a versificação, a melodia ou a mímica do intérprete. Essa redução constitui um trabalho pedagógico útil e talvez necessário, mas, de fato (no nível em que o discurso é vivido), ele nega a existência da forma. Essa, com efeito, só existe na "performance".

Todos estes aspectos teatrais, ambientais, o jogo, o espetáculo, que o extenso relato de Zumthor traz são elementos importantes que constituem sua noção de performance. E que, de uma certa maneira, ajudam a aproximar o efeito da performance de Obama sobre Mansfield da experiência de Zumthor e o camelô nas ruas de Paris. Para a performance, é necessário estarem ali a copresença de autor e espectador, o cenário que cerca o acontecimento, os sons e o ambiente, o corporal, o gestual e a palavra viva em movimento.

Essa necessidade da presença em uma situação performancial é que faz com que Zumthor ao ler o texto este "não ressuscitava nada", ou ao cantar a melodia na memória trazia uma "ilusão um pouco mais forte mas não bastava, necessariamente".

[...] Para além da materialidade do livro, dois elementos permanecem em jogo: a presença do leitor, reduzido à solidão, e uma ausência que, na intensidade da demanda poética, atinge o limite do tolerável.

E, no entanto... Na situação performancial, a presença corporal do ouvinte e do intérprete é presença plena, carregada de poderes sensoriais, simultaneamente, em vigília (ZUMTHOR, 2007, p. 68). [grifos nossos]

Ao longo de uma entrevista com André Beaudet, em Escritura e nomadismo: entrevistas e ensaios, Zumthor (2005) apresenta em, pelo menos dois momentos, uma espécie de síntese para a noção de performance. Primeiramente, ele a define como a materialização de uma mensagem poética através da voz humana e aquilo que a acompanha, como os gestos ou todos os movimentos corporais. Algumas páginas à frente, a performance aparece como algo "virtualmente teatral, em que se integram todos os elementos visuais, auditivos e táteis que constituem a presença de um corpo e as circunstâncias nas quais ele existe" (ZUMTHOR, 2005, p. 69). 
Ainda sobre todos estes elementos importantes para a noção de performance, a partir do trabalho de Zumthor, Heloísa Duarte Valente traz uma reflexão interessante a respeito do papel do ouvinte/receptor. Para Valente (1999), o receptor exerce uma função ativa e indispensável à performance.

[...] Ora, a combinação destes elementos (gesto, entoação da voz etc.) não se dá de forma aleatória. Ao lançar mão desses recursos, o cantor/ator/contador estabelece, na verdade, uma situação comunicativa que põe em ação interpretação, texto e ouvinte, o que quer dizer, o emissor necessita da resposta do receptor, ou seja, o ouvinte exerce função ativa que é indispensável na performance. Isto porque o ouvinte recria, de acordo com seu repertório particular, o universo significativo que lhe é transmitido pelo executante. Frisando a idéia, podemos mesmo afirmar que é justamente a participação ativa do ouvinte um dos determinantes fundamentais da performance do executante (VALENTE, 1999, p. 120). [grifo da autora]

O trabalho de Valente (1999) vai além de revisitar ou fazer remissões à noção de performance apresentadas nas obras de Zumthor. Uma de suas contribuições é o fato da autora problematizar a noção de performance - no caso de Zumthor ligada à poesia oral, principalmente medieval - e estendê-la a muitas outras formas de expressões.

[...] Tomando as idéias de Zumthor à letra, é necessário considerarmos
inicialmente um leque de níveis em que a performance é possível. Nesse caso,
temos uma imensa gama que inclui o teatro, as duplas de repentistas, o teatro de
marionetes, o discurso de palanque, a conferência científica, o show de rock, a
ópera, entre muitos outros - e, neste caso, ainda nos restringimos a uma
pequena amostragem que inclui apenas a viva voz, natural ou mediatizada
tecnicamente (VALENTE, 1999, p. 120). [grifos da autora]

Tomando a noção sobre performance de Paul Zumthor, e também se levando em conta as contribuições de Heloísa Duarte Valente, ficou claro que esta pressupõe a existência, a presença, de um corpo, de uma voz. Em relação à voz, Zumthor vai além de considerá-la importante e indispensável à performance. Segundo ele, a voz é um dos suportes indispensáveis ao que hoje conhecemos como literatura. "Admitir que um texto, num momento qualquer de sua existência, tenha sido oral é tomar consciência de um fato histórico que não se confunde com a situação de que subsiste a marca escrita, e que jamais aparecerá (no sentido próprio da expressão) 'a nossos olhos' (ZUMTHOR, 1993, p. 35). Admitindo, reconhecendo e, assim, valorizando o "fato de que a voz. ${ }^{3}$ foi então um fator constitutivo de toda obra que, por força de nosso uso corrente, foi denominada "literária"' (ZUMTHOR, 1993, p. 9).

${ }^{3}$ Grifos do autor 
Para melhor compreender esta relação, de quase dependência, entre os textos escritos e uma oralidade, é importante abordar a noção de índices de oralidade, de Zumthor:

[...] Por "índice de oralidade" entendo tudo o que, no interior de um texto, informa-nos sobre a intervenção da voz humana em sua publicação - quer dizer, na mutação pela qual o texto passou, uma ou mais vezes, de um estado virtual à atualidade e existiu na atenção e na memória de um certo número de indivíduos. $O$ índice adquire valor de prova indiscutível quando consiste numa notação musical, duplicando as frases do texto sobre o manuscrito (ZUMTHOR, 1993, p. 36). [grifos do autor]

Estes índices de oralidade seriam as marcas, as evidências, de que um dia, mesmo que remotamente, todo texto sofreu a intervenção de uma voz humana. É a força da voz, da palavra que um dia esteve em movimento. Palavra viva que, a partir de um determinado momento histórico, vai perdendo sua importância. E, assim, o domínio das tradições orais vai se marginalizando. Em troca disso, "o homem cria uma linguagem, abstrata, empenhando cada vez menos a realidade do corpo" (ZUMTHOR, 1993, p. 123). Esse recalque do corpo produzido pela supremacia da escrita acaba sendo um dos efeitos da preferência pela unicidade da escrita em detrimento de uma pluralidade de vozes.

Em A letra e a voz: a "literatura" medieval, Zumthor, em um trabalho genealógico, problematiza os momentos históricos em que a voz garantiu a existência e a perpetuação dos textos e escritos e como, aos poucos e principalmente após a invenção da imprensa, a literatura escrita acabou suprimindo os registros orais:

[...] Minha intenção não é chover no molhado provando a existência de uma oralidade medieval, mas valorizar o fato de que a voz foi então um fator constitutivo de toda obra que, por força de nosso uso corrente, foi denominada "literária" (ZUMTHOR, 1993, p. 9). [grifos do autor]

Algumas páginas adiante, ainda em A letra e a voz: a "literatura" medieval, Zumthor sintetiza e exemplifica um pouco dessa transição entre a oralidade e o texto escritural:

[...] O Ocidente entra passo a passo na idade da escritura, à qual os scriptoria carolíngios não tinham logrado impor um modelo. Daí um lento deslizar em direção ao que, desde 1200-50, um homem de outro planeta teria podido prever: uma predominância a longo prazo do modelo escritural. Consagrarei um capítulo a essa história. Entre o início do século XII e meados do século XV, por todo o Ocidente se produziu, em graus de fato diversos, uma mutação profunda, ligada à generalização da escrita nas administrações públicas, que levou a racionalizar e sistematizar o uso da memória. Donde uma extremamente lenta e dissimulada desvalorização da palavra viva. Recuando e caminhando com 
passos contados, entramos no mundo, como disse Octavio Paz, em que o destino final das literaturas é produzir obras vivas nas línguas mortas (ZUMTHOR, 1993, p. 28).

A questão da presença de um corpo que acaba sendo apagado/recalcado pela fixidez do texto escrito foi também problematizada pelo teórico literário Hans Ulrich Gumbrecht:

[...] Finalmente, podemos observar como o meio de comunicação, o impresso, rapidamente espalhou-se pela Europa acompanhando a invenção de Gutenberg dos tipos móveis por volta de 1450 . Definitivamente, o corpo humano não era mais o veículo de constituição do sentido; o corpo fora visivelmente separado do veículo do sentido, o livro, pela introdução de uma máquina, a prensa de impressão. Ao mesmo tempo em que era aliviado de sua função de veículo de sentido, o corpo era também liberado de sua função de fonte do sentido. Ao ler um livro, experiencíavamos, até muito recentemente, a consciência de um autor como fonte do sentido. O corpo fora separado da consciência da comunicação (GUMBRECHT, 1998, p. 73). [grifos nossos]

$\mathrm{Na}$ performance, este corpo, outrora apagado e recalcado, é responsável por abrigar/produzir o caráter físico da voz. A voz pensada não como responsável por emissão de fonemas, como articuladora de palavras. E sim, a voz como uma manifestação anterior a qualquer sistema de significação. A voz por ela mesma. Como propõe Zumthor (2007), a voz é uma coisa e, como toda parte de algo real, possui traços descritíveis e interpretáveis. Proposta de estudo da voz referenciada por Gumbrecht (1998, p. 146):

[...] A obra teórica do medievalista Paul Zumthor, por exemplo, tem se fixado nos últimos anos cada vez mais na voz. Mas voz não no sentido metafórico e relacionado ao discurso, como foi popularizado por Bakhtin. Ao contrário, Zumthor está interessado na qualidade físico-sensual da voz humana.

Voz que carrega em si os traços de cada sujeito que a emite, independente do conteúdo da mensagem. Ao ouvir Obama, é impossível que não pensar/imaginar no político de fala tranquila; homem de terno e gravata ou vestido sempre de maneira elegante; político negro eleito presidente em uma sociedade conservadora como a estadunidense. Enfim, a vOz percebida também como materialidade de Obama.

Propostas diferentes de pensar a voz, como faz Zumthor ao pensar a voz em lugar "em que a voz se dobra nela mesma, identifica-se com o sopro, de onde tantos outros simbolismos, recolhidos pelas religiões: o sopro criador, animus, rouab; a voz como poder de verdade" (ZUMTHOR, 2007, p. 85).

${ }^{4}$ Grifos nossos 
Proposta de desdobramento da voz nela mesma, a voz antes da fala, que encontra subsídios na obra de Adriana Cavarero. Proposta utilizada por Pedro de Souza, em Michel Foucault: o trajeto da voz na ordem do discurso:

[...] O mais importante do estudo de Cavarero - particularmente para o que
interessa a propósito do tema da voz em Michel Foucault - é o fato de salientar
que, situando-se antes da fala, a voz é puro grito originário. Daqui decorre
precisamente que a singularidade da voz ancora-se na total assimetria com
relação à ordem da fala. Pode-se então tomar a voz como pedra de toque do
sujeito enquanto fala, isto é, aquilo em que consiste sua singularidade. Não
interessa o que é dito no registro do conteúdo da fala, importa apenas a voz que
soa no dizer; esta é a que não se confunde com a esfera da fala (SOUZA, 2009,
p. 24).

Sopro criador, grito originário, desarticulada de qualquer rede significante. Apesar da importância do conteúdo do discurso político - seja para convencimento de eleitores indecisos, para legitimação de propostas de governo, para atacar o oponente - é um pouco destes aspectos/destas noções acerca da voz que são encontrados em algumas performances de Obama.

\section{A voz antes da fala: unicidade e materialidade} "It wasn't just one voice that shout it out before the walls in Jericho. All the voices came together,
a chorus of voices. That's what gives me hope."

Barack Obama $^{5}$

É comum que figuras políticas usem em seus discursos metáforas como de serem porta-vozes da população, ou que em seus pronunciamentos nos palanques é o povo quem fala. Porém, no caso das falas de Obama, fica claro um posicionamento em relação à voz, e seu uso, de uma forma diferente destas. Aliás, a temática da voz foi uma constante em quase todos os discursos em sua campanha presidencial nas eleições de 2008. Expressões como "milhões de vozes foram ouvidas", "com suas vozes e seus votos", "milhões de vozes chamando por uma mudança", "suas vozes fizeram a diferença" fizeram parte do repertório das performances vocais de Obama durante a corrida eleitoral. Um discurso em específico, intitulado The great need of the our, traz uma performance em que Obama ressalta o caráter material da voz, da força desta voz que é um grito originário, uma voz antes da fala:

${ }^{5}$ Trecho do discurso de Barack Obama intitulado "The great need of the hour". Disponível em: $<$ http://www.youtube.com/watch?v=Kf0x_TpDris $>$. 
[...] The Scripture tells us that when Joshua and the Israelites arrived at the Gates of Jericho, they could not enter. The walls of the city were too steep for any one person to climb; too strong to be taken down with brute force. And people sat for days, unable to pass on trough.

But God had a plan for his people. He told them to stand together and march together around the city, and on the seventh day he told them that they heard the sound of the ram's horn, they should speak with one voice. And at the chosen hour, when the horn sounded and a chorus of voices cried out together, the mighty walls of Jericho came tumbling down (OBAMA, 2008).

Nesse trecho de seu discurso, Obama cita a passagem bíblica dos Hebreus (11:30-31) e evoca uma voz que não é fala, não é articulada. Uma voz, ou um coro de vozes, que, de acordo com as Escrituras, foi capaz de derrubar as muralhas de Jericó.

Adriana Cavarero (2005, p. 20), em For more than one voice: toward a philosophy of vocal expression, revela este caráter de uma VOZ antes de qualquer unidade de significação presente na tradição hebraica: "According to the Bible, God's Power - wich manifests itself to the people of Israel through creation and revelation - finds its expression in breath, ruah, and in the voice, qol." Algumas linhas à frente, Cavarero explica o caráter de qol, que transcende o caráter da voz apenas como fala:

[...] Significantly, besides indicating the voice, qol also indicates the acoustic effect of the wind and the storms, and above all, thunder. Qol is similar in its power and its modes of manifestation to ruab but is distinguished by way of sound. Just as happens with the Greek word phone, qol refers to the acoustic sphere and refers to everything that is perceptible by the ear (CAVARERO, 2005 , p. 20). [grifos nossos]

Ainda segundo Cavarero, na tradição hebraica qol e ruah são as fontes de comunicação com Deus e pertencem a uma esfera anterior ao speech (traduzido livremente aqui como discurso/fala). Para a autora, foi a releitura do Velho Testamento feita pela tradição cristã que acabou perpetuando a noção da criação através do discurso/fala. "For ancient Israel, neither creation nor self-revelation come from the speech of God but rather from his breath and from his voice" (CAVARERO, p. 20).

A leitura que Pedro de Souza faz sobre a obra de Cavarero traz uma síntese interessante em que fica ratificada a condição de uma noção de vOz com uma autonomia sobre a fala:

[...] Outro étimo importante que sustenta a autonomia da noção de voz, qol, em relação à fala. Cavarero reporta-se ao que se lê no início de Gênesis: "Deus disse". Aqui, a palavra usada na língua hebraica é Amar. No texto hebreu, amar significa falar como ato de proferir sentido, de expressar. Contudo, quando aparece na bíblia e no uso comum refere-se a situações que se pressupõe uma interação verbal entre um ouvinte e um interlocutor. Amar assim designa um ato

56 fragmentum, N. 36. Laboratório Corpus: UFSM, Jan./ Mar. 2013 
enunciativo cujo aspecto acústico liga-se a uma função de expressar um conteúdo. Já a palavra qol reduz-se a um fenômeno acústico puro, desligado de qualquer conteúdo semântico. Em síntese, enquanto amar (falar/dizer) compõe uma dimensão acústica e semântica, qol (voz) compõe uma dimensão genuinamente acústica (SOUZA, 2009, p. 24). [grifos do autor]

Uma análise que mostra como se pode pensar um objeto de estudo a partir desta noção de voz é, competentemente, apresentada por Souza (2009). O pesquisador debruça-se sobre os gestos vocais do filósofo Michel Foucault, a prosódia das falas do filósofo, para poder apreender o sujeito-filósofo se constituindo e como Foucault constitui sua própria voz:

[...] como caixa de ressonância a ecoar o grito dos fracos contra os poderosos, sem se importar tanto o que se diz ao gritar, mas o desenho da relação que se estabelece e faz irromper sonoramente o confronto da voz silenciada com a ordem que a silencia (SOUZA, 2009, p 34).

Dessa maneira, Souza (2009, p. 35) pretende no tom da voz a tessitura na qual "a singularidade do dizer toma corpo no fio do discurso".

Outra interessante análise sobre o estatuto da voz em sua unicidade e materialidade é a leitura que Cavarero (2005) traz a partir de A king listens, de Ítalo Calvino. A autora chama atenção ao fato de que o rei da obra de Calvino controla toda a atividade de seu palácio através da escuta e da tentativa de interpretação dos sons que o cercam. Porém, esses sons não são articulados em palavras, ou, pelo menos, não importa o seu valor semântico e sim suas substâncias fônicas. O objetivo do rei era identificar, perceber, no timbre das vozes que o cercavam, qualquer sinal de falsidade, de traição, de perigo ao seu trono. Até que:

One fine Day, "when in the darkness a woman's voice is released in singing, invisible at the sill of an unlighted window", the insomniac king happens to hear her. And he is aroused; he finally remembers life and rediscovers in her voice an object for his long-lost desires. The king's knew emotion certainly does not depend on the song she sings, which he had heard many times before: nor does it depend on the woman herself, whom he has never seen. Rather, Calvino explains, the king is "attracted by that voice as a voice, as it offers itself in song". What attracted him, in other words, is the "pleasure this voice puts into existing: into existing as voice; but this pleasure leads you to imagine how this person might be different". In short, the king discovers the uniqueness of each buman being, as it gets manifested in the uniqueness of the voice (CAVARERO, 2005, p. 2). [grifos nossos]

Para Cavarero (2005), esta obra de Calvino é importante por ser um dos poucos textos que encorajam, incitam, uma investigação da voz com toda a riqueza que este objeto pode oferecer. Este resgate da riqueza, unicidade e materialidade da vOz vai de encontro a toda uma tradição filosófica que 
privilegia uma abordagem de um universalismo abstrato. O que acaba guiando a voz para uma história que a relega à insignificância.

O desafio de Cavarero (2005, p. 13), segundo a própria autora, é ambicioso, mas simples:

[...] In elementary terms, it consists in thinking of the relationship between voice and speech as one of uniqueness that, although it resounds first of all in the voice that is not speech, also continues to resound in the speech to which the human voice is constitutively destined. The vocal communication of uniqueness, although it inheres exclusively in the register of sound, in fact ends up being essential to that destination. Meaning - or better, the relationality and the uniqueness of each voice that constitutes the nucleus of this meaning passes from the acoustic sphere to speech. Precisely because speech is sonorous, to speak to one another is to communicate oneself to others in the plurality of voices. In other words, the act of speaking is relational: what it communicates, is the acoustic, empirical, material relationality of singular voices.

Um dos problemas encontrados por Cavarero, e sua intenção de resgatar a corporeidade e materialidade da voz, é o fato de ter se atribuído, equivocadamente, à expressão e noção de speech (traduzido livremente aqui como discurso) uma ideia de esfera verbal. "Cut off from the throats of those who emit it, speech undergoes a primary devocalization that leaves it with only the depersonalized sound of a voice in general" (CAVARERO, 2005, p. 14). Portanto, resgatar a primazia da voz em relação ao discurso, embora ambicioso e simples, ainda permanece um desafio.

\section{Performance mediatizada e o efeito das novas tecnologias}

Antes de retomar a análise de alguns aspectos da performance de Obama, em The great need of the our, é importante abordar alguns dos aspectos que a torna possível. Como ter acesso ao áudio e à imagem, e de boa qualidade, de um discurso proferido pelo então candidato à presidência de um país tão distante e que aconteceu há mais de dois anos? Em uma sociedade mergulhada em tecnologia de armazenamento, manipulação e execução de áudio/imagem, esta pergunta pode parecer sem sentido ou, no mínimo, é facilmente respondida. O acesso pode ser feito via ferramenta de busca do Google, acessando o YouTube, fazendo o download do arquivo em sites ou programas de compartilhamento etc. Mas nem sempre foi assim. Nem sempre foi tão simples dissociar o som, ou a imagem, do seu espaço e tempo de produção. Esta capacidade de dissociação foi classificada por R. Murray Schafer - e problematizada por Heloísa Duarte Valente, em As vozes da canção na mídia - como esquizofonia. 
[...] A paisagem sonora do século XX caracteriza-se por alguns traços que a diferencia de todos os tempos que o antecederam. No caso específico da música e das linguagens sonoras, pode-se afirmar que, pela primeira vez na história, énos dada a possibilidade de replicar, modificar, guardar os eventos sonoros, ainda que de forma rudimentar. Em outras palavras, trata-se do momento de criação das mídias eletromagnéticas e, posteriormente, eletrônicas e computacionais. Esse fenômeno foi definido por Murray Schafer (1979) como esquizofonia e se refere à possibilidade de dissociar o som de seu espaço-tempo de produção e reprodução acústica (VALENTE, 2003, p. 32). [grifos da autora]

Para Valente (2003), essas novas tecnologias não só permitiram o que foi classificado como esquizofonia, tornando possível o acesso a performances separadas de seu espaço/tempo de produção, como trazem modificações na própria performance e na maneira de percebê-la. Retomando mais uma vez tal noção de Paul Zumthor, Valente (2003, p. 70) entende que em uma performance mediatizada tecnicamente ocorre uma defasagem no eixo espaço-tempo. Ou seja, e ainda segundo a autora em questão, o momento da interpretação não é necessariamente o mesmo da recepção. Para Valente (2003), embora alguns elementos da performance ao vivo estejam presentes naquela mediatizada, perde-se a tatilidade, o peso, o volume e alguns outros componentes que compõem a sua atmosfera.

Essa é uma questão que suscita algumas reflexões importantes sobre a performance de Obama. Primeiramente, quando pensada sob o ponto de vista das pessoas que comparecem pessoalmente aos comícios, aos pronunciamentos, às falas de Obama: elas estariam presenciando uma performance ao vivo? Sem interferência de aparatos técnicos? Sob o ponto de vista de estarem presentes no momento da emissão da mensagem, sim. Mas, certamente, esta performance vai sofrer interferências de todo um aparato técnico para garantir que a mensagem chegue às milhares de pessoas que estão ali presentes. Amplificadores, caixas de som, microfone, câmeras para gravação e futura transmissão do discurso, ou de pelo menos parte dele: todos esses, "aparelhos que se transformam numa expansão do corpo humano" (VALENTE, 2003, p. 94). Portanto, pode-se concluir que, mesmo acompanhando o discurso no local onde está acontecendo, as pessoas estão diante de uma voz amplificada, artificializada, de Obama; estão diante de um corpo de Obama com uma extensão artificial. Essa interferência é ainda maior para aqueles que ouvem ou assistem a performance através de alguma mídia, como a internet, televisão, rádio etc. Além do deslocamento e da defasagem do eixo espaço/tempo da enunciação, a não presença - como foi dito anteriormente - faz com que se perca a tatilidade, o peso, a percepção dos elementos componentes da atmosfera que cerca aquela performance. Essa perda já foi competentemente traduzida no exemplo de Paul Zumthor no início deste trabalho. 
Em relação ao aparato técnico que cercam, e tornam possíveis, algumas performance mediatizadas nos dias de hoje, é importante ressaltar o uso do microfone. Vale a pensa ressaltar que:

[...] se não fosse o microfone - e, junto com ele, todos os equipamentos de amplificação do som - os grandes festivais de rock que surgiram a partir da década de 1960 e todo os mega-eventos (os comícios politicos, os shows em estádios esportivos, o próprio carnaval de rua nordestino e das passarelas) não teriam existido. Somente a introdução dessas mídias possibilitaria a reunião simultânea de milhares de pessoas. O progressivo aprimoramento técnico (alta-fidelidade, potência), nesse sentido, contribui para que, a cada dia, massas humanas cada vez maiores de freqüentadores aglomerem o espaço. Reciprocamente, a performance deverá encontrar caminhos para se adaptar a essa paisagem sonora cambiante (VALENTE, 2003, p. 110). [grifos nossos]

Adotando essa proposição de Valente, fica claro que o microfone e outras tecnologias acabaram por se tornar extensões do corpo do político, do cantor, do músico em suas performances. Seja para as pessoas que vão assistir às performances de Obama ao vivo, seja para quem as acessa através das mídias, o microfone é indispensável para a transmissão da mensagem, da percepção da voz etc. Enfim, o microfone já faz parte da performance. Já é também constitutivo dela.

Essa paisagem sonora que se torna cada vez mais esquizofônica e que também sofre intervenções/alterações dos novos aparatos técnicos acaba por alterar o modo de escutar, ver, perceber qualquer tipo de performance. Mesmo que a análise proposta neste trabalho tenha a intenção de se fixar apenas nos aspectos vocais do discurso de Obama, é importante ressaltar que o uso da imagem, estática e em movimento, trouxe algumas mudanças importantes para o modo de se executar e perceber a performance. O surgimento e popularização da fotografia e, posteriormente, do cinema e a possibilidade de ver o artista/político em movimento fez com que a importância da imagem do artista/político ganhasse outra dimensão. A performance passa a ser ouvida e vista com muito mais frequência, ainda mais com as tecnologias de armazenagem e repetição de som/imagem. Consequentemente, o corpo, os gestos, a imagem, passam a compor a performance do artista. Todo este apelo à imagem faz com que Heloísa Duarte Valente (2003) proponha o termo "ouvendo" para a sua recepção/percepção . Por esse motivo é que, mesmo que a reflexão proposta se fixe na voz de Obama com todo este apelo à imagem, é impossível não "ouver" - mesmo que apenas nas imagens que vêm à mente - os gestos de Obama, o corpo negro e magro, o político de postura comedida, a figura carismática etc. 


\section{"The great need of the hour"}

Basicamente, o discurso de Obama, The great need of the our, trata da necessidade de união entre todos os cidadãos americanos para que possam superar, ou ao menos começar a tentar, os problemas e dificuldades que os Estados Unidos enfrentavam ${ }^{6}$. Completando o título de seu discurso, Barack Obama evoca as palavras o ativista político negro Martin Luter King para ressaltar: "Unity is the great need of the our" (OBAMA, 2008). Além dos problemas gerados pelo déficit da balança comercial do país, pelo déficit orçamentário, era mais importante e urgente superar um déficit moral existente na sociedade americana:

[...] I'm talking about an empathy deficit. The inability to recognize ourselves in one another; to understand that we are our brother's keeper; we are our sister's keeper; that, in the words of Dr. King, we are all tied together in a single garment of destiny.

We have an empathy deficit when we're still sending our children down corridors of shame - schools in the forgotten corners of America where the color of your skin still affects the content of your education.

We have a deficit when CEOs are making more in ten minutes than ordinary workers make in an entire year; when families lose their homes so unscrupulous lenders can make a profit; when mothers can't afford a doctor when their children are striking wit illness.

We have a deficit in this country when we have Scooter Libby justice for some and Jena justice for others; when our children see hanging nooses from a schoolyard tree today, in the present, in the twenty-first century. We have a deficit when homeless veterans sleep on the streets of our cities; when innocents are slaughtered in the deserts of Darfur; when young Americans serve tour after tour after tour after tour of duty in a war that should've never been authorized and never been waged. We have an empathy deficit on this country that has to be close (OBAMA, 2008).

O principal obstáculo para que essa união pudesse ser alcançada, e que foi tema recorrente em diversos discursos de Obama desde o início de sua candidatura até o intitulado "Discurso da vitória", era o fato de existir uma forte tendência de divisão entre os americanos. Uma muralha dividia democratas e republicanos, brancos e negros, cristãos e muçulmanos, americanos e imigrantes. Não seria fácil alcançar essa união. "We are told that those who differ from us on a few things are different from us on all things; that our problems are the fault of those who don't think like us or look like us or come from where we do" (OBAMA, 2008). O que tornava essa união ainda

\footnotetext{
${ }^{6}$ Sem a necessidade de explicações mais técnicas ou aprofundadas, vale à pena registrar que o discurso de Obama em questão foi proferido no início de 2008, ano do auge da crise financeira americana.
} 
mais distante era o fato de haver uma política que tenta dividir o país: "that puts up walls between us" (OBAMA, 2008).

Muralhas, que foram derrubadas pelos hebreus na passagem citada por Obama no início de seu discurso, também estão obstruindo o caminho da união dos americanos. Muralhas que precisam ser derrubadas. E, novamente, a exemplo da passagem bíblica, a voz parece ser a ferramenta para trazer a baixo essas estruturas. Pelo menos, esta é uma das conclusões que algumas passagens da performance vocal de Obama, em The great need of the our, parecem sugerir. $O$ conteúdo do discurso é sobre a necessidade de união. Uma necessária união, embora difícil de ser alcançada. A voz de Obama materializa isso. Nos gritos, na soma de vozes, a sua; no uso de sua voz, Obama acredita ser possível começar a abalar as estruturas destas muralhas:

[...] And if enough of our voices join together; we can bring those walls tumbling down. The walls of Jericho can finally come tumbling down. That is our hope - but only if we pray together, and work together, and march together (OBAMA, 2008).

Ultrapassando a esfera do conteúdo do discurso de Obama - onde sua voz também é importante pelo fato de ser o veículo para esta comunicação/mensagem - para a análise do caráter puramente acústico de sua performance, como propõem os trabalhos de Cavarero e Zumthor, chama atenção a maneira como Obama eleva seu tom de voz, chegando aos gritos, nas passagens onde propõe que a união de vozes pode mover obstáculos. Além de propor que a união de vozes constitui uma força capaz de derrubar muralhas, é preciso apresentar uma voz forte, um grito, encorpada. Enfim, na voz opera-se a corporificação desta força. Isso pode ser percebido nos seguintes trechos:

[...] By itself, that single moment of recognition between that young white girl and that old black man is not enough to change the country. By itself, it is not enough to give health care to the sick, or jobs to the jobless, or education to our children. But it is where we begin. (I)

[...] It is why I believe the walls in that room began to shake at that moment. (II)

[...] And if they can shake in that room, they can shake here in Atlanta.

And if they can shake in Atlanta, they can shake in the state of Georgia. And if they can shake in Georgia, they can shake all across America. (III)

[...] And if enough of our voices join together; if we see each other in each other's eyes, we can bring those walls tumbling down. The walls of Jericho can finally come tumbling down. (IV) 
$[\ldots]$ That is our hope - but only if we pray together, if we work together, and if we march together. (V)

No primeiro trecho, Obama discursava mais próximo de sua maneira de costume: embora com a voz em um volume um pouco alto, apresentava uma leitura pausada, estilo comedido. O (II) trecho, onde era preciso chamar atenção para o fato de que as "estruturas começaram a balançar", representa uma virada significativa na performance vocal de Obama: traz à cena uma voz mais grave, forte, com ênfase na palavra shake. A partir deste momento, o tom e o volume da voz aumentam; a intensidade na pronúncia - ainda com ênfase na expressão shake - das palavras segue em ascendência; Obama chega aos gritos entre as metades do (III) e do (IV) trecho; a respiração e as pausas deixam claro que Obama demonstra cansaço no fim destas partes. Assim como Cavarero (2005) atenta para o fato de que o rei do texto de Calvino é atraído pela voz de uma cantora por ela mesma, sem importar o valor semântico que estava sendo dito/cantado, nestes trechos o mais importante parece ser a intensidade, a força, o gesto vocal de Obama e não o valor semântico do que estava sendo dito, às vezes, gritado.

Obama fez mais do que, através de seu discurso, abordar a importância da união das vozes para superar o "déficit moral" do país e derrubar a muralha que divide os americanos. A voz de Obama materializava o esforço que era preciso para se atingir a tão difícil união, o cansaço marcado na vOz era resultado da dificuldade em balançar as estruturas até que elas viessem ao chão. Esforço que faz com que, ao final do trecho (IV) e no início do (V), Obama retome o seu estilo mais comedido, uma maior pausa entre as palavras, com uma voz em tom e volume mais baixos.

Em outro momento, e de uma maneira distinta do que foi apresentado anteriormente, a voz aparece como instrumento importante para mover os obstáculos que impedem a união do povo americano. Obama muda um pouco a narrativa de seu discurso para contar a história de uma garota de 23 anos, branca, chamada Ashley Baia. Ashley organizava encontros e discussões de eleitores pró-Obama. Em um destes encontros em uma mesa-redonda, foi questionada sobre a razão de votar em Barack Obama. Ela relatou que, aos nove anos de idade, foi diagnosticado um câncer em sua mãe que foi, então, demitida e, consequentemente, perdeu assistência do plano de saúde. Mesmo com apenas nove anos. Ashley percebeu que um dos maiores gastos de sua família era com alimentação e, para ajudar sua mãe, decidiu que passaria a comer somente sanduíches de mostarda. Foi assim que a menina se alimentou por mais de um ano até que sua mãe se curou. Então, Ashley argumentou ter escolhido Obama por sua proposta de mudança no sistema de saúde americano e para que ninguém tivesse que viver o que ela viveu. A reunião continuou e muitas pessoas contaram, em voz-alta, suas razões de 
apoiar a candidatura de Obama. Até que, após todos terem falado, um idoso, negro, que estava no fundo da sala foi questionado sobre qual o motivo de votar em Obama. Sua razão não era o fato de Obama ser negro como ele, nem a proposta da reforma do sistema de saúde ou alguma razão econômica: "I am here because of Ashley" (OBAMA, 2008).

Aqui, a voz aparece como um espaço de constituição de dois sujeitos distintos: uma mulher jovem e branca e seu oposto, um negro de idade avançada. Além disso, Obama sequer dá maiores informações sobre a história de vida, sequer o nome, do sujeito negro. A única existência deste sujeito se dá por sua voz. É uma voz de apenas uma frase. Mas, é importante para o que Obama vai chamar atenção alguns instantes adiante: "By itself, that single moment of recognition between that young white girl and that old black man is not enough to change the country". A voz, palavra viva circulando em uma sala, foi capaz de criar este vínculo de reconhecimento entre dois sujeitos tão opostos e que estavam tão separados em um país onde existe uma política a serviço da divisão das pessoas. Segundo Obama (2008), se esse momento de vínculo entre estes dois sujeitos, constituídos através de suas vozes, não foi suficiente para mudar o país, foi responsável por balançar as estruturas da sala onde os dois sujeitos se encontraram.

A história destes dois personagens citados serve, para Obama, como um espaço narrativo onde pode ser percebida a importância, a necessidade, da derrubada das muralhas que dividem os americanos e da importância que a voz tem nesse processo.

[...] Brothers and sisters, we cannot walk alone. In the struggle for justice and for equality, we cannot walk alone. In the struggle for opportunity and justice, we cannot walk alone. In the struggle to heal this nation and repair the world, we cannot walk alone.

So I ask you to walk with me, and march with me, and join your voice with mine, and together we will sing the song that tears down the walls that divide us, and lift up an America that is truly indivisible, with liberty, and justice, for all (OBAMA, 2008). [grifos nossos]

Estas breves reflexões acerca da performance de Barack Obama são resultado, e podem servir como incentivo, de uma postura em relação à voz que tenta restituir sua riqueza e materialidade. Embora, como apontou Silvia Adriana Davini (2008, p. 307), ainda seja tão complexo responder questões, aparentemente simples, como o "que é a voz? Onde ela se dá quando eu falo?”, parece ser cada vez mais imperativo pensar a voz não somente como uma ferramenta para comunicação ou apenas como palavra oralizada. Ainda, buscando apoio novamente em Davini, perceber que: "Não 'usamos' a voz. A voz 'habita' corpo e linguagem" (DAVINI, 2008, p. 314). 


\section{REFERÊNCIAS}

CAVARERO, Adriana. For more than one voice: toward a philosophy of vocal expression. Tradução: Paul A. Kottman. Stanford: Stanford University Press, 2005.

DAVINI, Silvia Adriana. Voz e palavra: música e ato. In: MATOS, Cláudia Neiva de; TRAVASSOS, Elizabeth; MEDEIROS, Fernanda Teixeira de. Palavra cantada: ensaios sobre poesia, música e voz. Rio de Janeiro: 7 Letras, 2008.

GUMBRECHT, Hans Ulrich. Modernização dos sentidos. São Paulo: 34, 1998.

MANSFIELD, Stephen. O Deus de Barack Obama: porque não existe liderança sem fé. Tradução de Nathalia Molina. Rio de Janeiro: Thomas Nelson Brasil, 2008.

OBAMA, Barack Hussein. The great need of the hour. 2008. Disponível em: $<$ http://www.youtube.com/watch?v=Kf0x_TpDris>. Acesso em: 19 jan. 2011.

SOUZA, Pedro de. Michel Foucault: O trajeto da voz na ordem do discurso. Campinas, SP: RG, 2009.

VALENTE, Heloísa Duarte. Os cantos da voz: entre o ruído e o silêncio. São Paulo: Anna Blume, 1999.

. As vozes da canção na mídia. São Paulo: Via Lettera, 2003.

ZUMTHOR, Paul. A letra e a voz: A "literatura" medieval. Trad. por Amálio Pinheiro e Jerusa Pires Ferreira. São Paulo: Companhia das letras, 1993.

Editorial, 2005.

Escritura e nomadismo: entrevistas e ensaios. São Paulo (SP): Ateliê . Performance, recepção, leitura. Tradução: Jerusa Pires Ferreira e Suely Fenerich. 2. ed. São Paulo: Cosac Naify, 2007. 